\title{
Medievalista
}

Online

16 | 2014

Número 16

\section{In memoriam. Jacques Le Goff (1924-2014)}

José Mattoso

\section{(2) OpenEdition}

\section{Journals}

Edição electrónica

URL: http://journals.openedition.org/medievalista/1399

DOI: 10.4000/medievalista.1399

ISSN: 1646-740X

\section{Editora}

Instituto de Estudos Medievais - FCSH-UNL

\section{Refêrencia eletrónica}

José Mattoso, «In memoriam. Jacques Le Goff (1924-2014) », Medievalista [Online], 16 | 2014, posto online no dia 01 dezembro 2014, consultado o 23 setembro 2020. URL : http://

journals.openedition.org/medievalista/1399; DOI : https://doi.org/10.4000/medievalista.1399

\section{(ब) $(1)($}

Mediavalista está licenciado com uma Licença Creative Commons - Atribuição-NãoComercial 4.0 Internacional. 
Revista ISSN 1646-740X

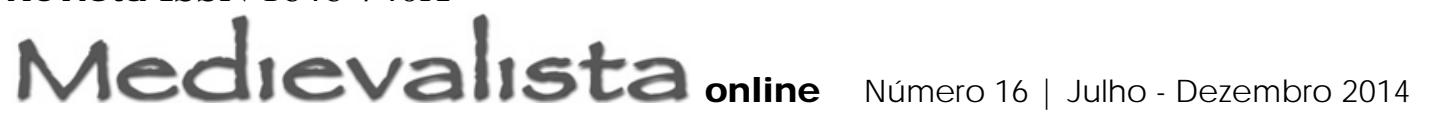

Título: In memoriam. Jacques Le Goff (1924-2014)

Autor(es): José Mattoso

Universidade: Universidade Nova de Lisboa

Faculdade e Departamento / Unidade de Investigação: Faculdade de Ciências Sociais e

Humanas - Instituto de Estudos Medievais

Código Postal: 1069-061 LISBOA

Cidade: Lisboa

País: Portugal

Contacto: jjmtts@outlook.com

Fonte: Medievalista [Em linha]. Direc. José Mattoso. Lisboa: IEM.

Disponível em: http://www2.fcsh.unl.pt/iem/medievalista/

ISSN: 1646-740X

Data do texto: 27 de Maio de 2014 


\section{In memoriam. Jacques Le Goff (1924-2014)}

\section{José Mattoso}

Por ocasião da morte de Jacques Le Goff, no passado dia 1 de Abril, alguns dos jornais que davam a notícia, sobretudo os franceses, chamavam-lhe "l'ogre historien". Se em francês a metáfora não se compreende facilmente, muito menos se percebe em português. Alguns dos autores franceses que a usaram tiveram o cuidado de a explicar. O certo é que a alcunha, digamos assim, teve sucesso. É o que se depreende de ter sido empregue por vários jornais e estes lhe terem dado grande relevo.

O ogre é uma entidade que aparece frequentemente nos contos populares do Norte da Europa. É um monstro que mete medo a toda a gente, se alimenta de carne humana e nunca está saciado. As versões modernas atenuam a sua ferocidade, identificando-o com o romântico personagem masculino de A Bela e o Monstro ou acentuam o contraste entre os dois aspectos de Shrek, o herói do filme de desenhos animados americanos, fisicamente disforme, mas ousado e protector.

Até aqui, parece que nada disto tem que ver com Le Goff. A atribuição deve-se aos seus discípulos Jacques Revel e Jean-Claude Schmitt que, em 1998, reuniram e publicaram uma miscelânea de estudos em honra do seu mestre, a que deram o título L'ogre historien. Autour de Jacques Le Goff. A alcunha pegou. Mas é uma citação. Baseia-se numa frase célebre de Marc Bloch, que, numa passagem da sua obra Apologie pour l'histoire ou métier d'historien (1949), compara o "bom historiador" a um "ogre", devorador insaciável de carne humana, ou seja, explorador incansável dos vestígios da acção humana nos despojos do passado: "O bom historiador”, diz Marc Bloch, "assemelha-se ao ogre da lenda. Onde fareja carne humana, ele sabe que está a sua caça”.

É preciso dizer, porém, que a identificação de Le Goff com um ogre não se deve a qualquer espécie de ferocidade, mas à sua capacidade para em tudo ver História. Esta qualidade deve existir em qualquer bom historiador. Em Le Goff, evidenciou-se pelo 
número de obras que escreveu, pela variedade de temas que explorou e pela multiplicidade de fontes históricas a que recorreu, mas também pela sua impressionante capacidade de trabalho, e até pelo seu aspecto físico. De facto, era corpulento como uma montanha, mas a sua imponência não o tornava frio nem distante. Transparecia nele a autoridade, mas sem excluir o dom do acolhimento. As suas qualidades de chefia fizeram dele, durante dezenas de anos, o director da revista Annales e o responsável por um seminário de História Medieval na École Pratique des Hautes Études en Sciences Sociales. Não posso esquecer o ambiente de cordialidade, de exigência crítica e de espírito de equipa que envolvia o seu seminário, no qual tive o privilégio de participar em 1990. Não admira que tenha marcado com a sua personalidade invulgar a corrente historiográfica francesa que dominou de forma brilhante os meios universitários de todo o mundo entre os anos 50 e o fim do século XX, sobretudo nos países da Europa meridional e da América do Sul.

Tal como o monstro, que devorava tudo, também ele de tudo fazia História: dos "intelectuais", do trabalho, da memória, do tempo, da escrita, da Europa, das lendas hagiográficas, dos santos (S. Luís, rei de França, e S. Francisco de Assis), do Purgatório, do imaginário (que há de mais diverso e mais ilimitado do que o imaginário?)... Estudou toda a espécie de documentos: cruzes, formulários litúrgicos, gestos, vestuário, emblemas, tratados de Filosofia e Teologia Escolástica, símbolos, imagens, "exemplos", sermões, insígnias, crenças, sacramentos, indulgências, ideias políticas... Tudo isto situado no seu contexto, enquadrado pela respectiva época, inserido no respectivo grupo social, dependente de determinados sistemas sociais e económicos, sujeito a mudanças de grande amplitude, diferenciado pelas variáveis geográficas do espaço que ocupa. Tal como o monstro capaz de devorar tudo o que cheira a humanidade, também Jacques Le Goff descobria indícios de História em tudo o que tivesse a marca do Homem.

Foi dessa marca, por mais ténue que ela se apresentasse, que Le Goff tratou como poucos o souberam fazer. Assim nos ajudando a desvendar a vida dos homens e das mulheres da Idade Média.

\section{COMO CITAR ESTE ARTIGO}

\section{Referência electrónica:}

Medievalista online № 16| J ulho - Dezembro 2014 ○IEM - Instituto de Estudos Medieva is 3 www2.fc sh.unl.pt/iem/med ieva lista 
MATTOSO, José - “In memoriam. Jacques Le Goff (1924-2014)”.

Medievalista [Em linha]. №16 (Julho - Dezembro 2014). [Consultado dd.mm.aaaa].

Disponível em http://www2.fcsh.unl.pt/iem/medievalista/MEDIEVALISTA16। ISSN 1646-740X.

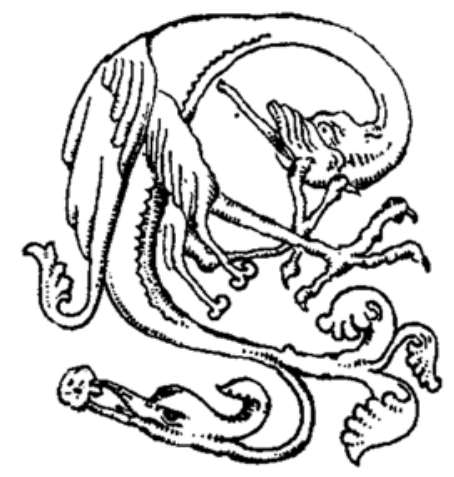

